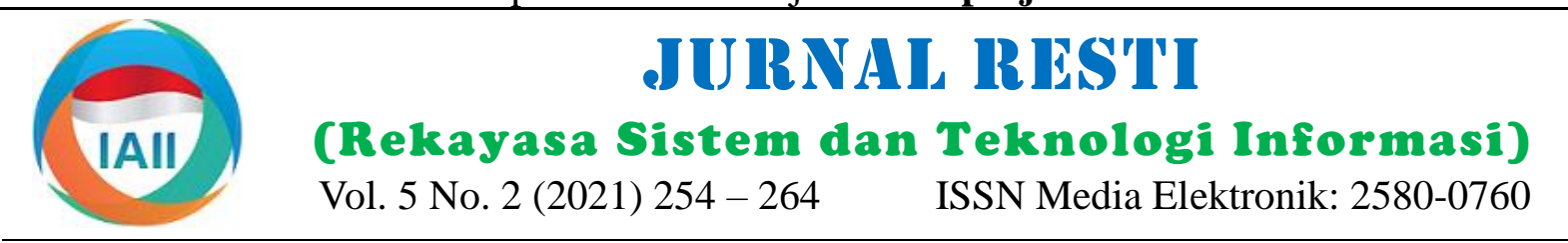

\title{
Algoritma Fungsi Perlatihan pada Machine Learning berbasis ANN untuk Peramalan Fenomena Bencana
}

\author{
Anjar Wanto ${ }^{1,2}$, Sarjon Defit ${ }^{2}$, Agus Perdana Windarto ${ }^{1,2}$ \\ ${ }^{1}$ STIKOM Tunas Bangsa, Pematangsiantar, Indonesia \\ ${ }^{2}$ Department of Informatics Engineering, Universitas Putra Indonesia YPTK Padang, Indonesia \\ anjarwanto@amiktunasbangsa.ac.id, sarjond@yahoo.co.uk, agus.perdana@amiktunasbangsa.ac.id
}

\begin{abstract}
Research has been carried out with several training functions using standard backpropagation methods, One-Step Secant (OSS), and Bayesian regulation. The purpose of this study was to (i) analyze the Performance accuracy (Performance) of the standard backpropagation method and (ii) optimize the training function with the One-Step Secant (OSS) and Bayesian regulation methods to obtain comparison results of the three methods in the search for the best results implementation of disaster phenomenon forecasting data. The research method is based on quantitative methods with times-series data on disaster phenomena in Indonesia over the last ten years (2011-2020) which were analyzed using two network architecture models, namely 4-8-1 and 4-10-1. The results showed that the 4-8-1 architectural model with the Bayesian regulation training function method was able to optimize quite well through accelerating training time and resulted in a low MSE measurement, although not the lowest with an epoch value of 197 iterations and a Performance of 0.0148480766. The lowest epoch value is generated by the OSS method, but it Performs poorly. The best Performance is produced by the standard backpropagation method with the traingd training function, but the training process for achieving convergence is also too long. In general, it can be concluded that the 4-8-1 architectural model with Bayesian regulation can be used to predict (predict) the phenomenon of natural disasters in Indonesia because the training time to achieve convergence is not too long and Performs exceptionally well.
\end{abstract}

Keywords: ANN, bayesian regulation, Performance, backpropagation method, One-Step Secant.

\begin{abstract}
Abstrak
Telah dilakukan penelitian dengan beberapa fungsi perlatihan dengan metode backpropagation standard, One-Step Secant (OSS), dan Bayesian regulation. Tujuan penelitian ini untuk (i) menganalisis keakuratan kinerja (Performance) metode backpropagation standard dan (ii) melakukan optimasi fungsi perlatihan dengan metode One-Step Secant (OSS) dan Bayesian regulation, sehingga diperoleh hasil pembandingan dari ketiga metode tersebut dalam pencarian hasil terbaik untuk pelaksanaan data peramalan fenomena bencana. Metode penelitian berbasis metode kuantitatif dengan data times-series fenomena bencana di Indonesia pada kurun waktu 10 tahun terakhir (2011-2020) yang dianalisis dengan dua model arsitektur jaringan, yakni 4-8-1 dan 4-10-1. Hasil penelitian ditunjukkan, bahwa model arsitektur 4-8-1 dengan metode fungsi perlatihan Bayesian regulation mampu dengan optimasi cukup baik melalui pemercepatan waktu perlatihan dan dihasilkan pengukuran MSE rendah walaupun bukan paling rendah dengan nilai epoch sebesar 197 iterasi dan kinerja sebesar 0,0148480766. Nilai epoch paling rendah dihasilkan oleh metode OSS, tetapi berkinerja kurang baik. Kinerja terbaik dihasilkan oleh metode backpropagation standard dengan fungsi perlatihan traingd, tetapi proses perlatihan untuk pencapaian konvergensi juga terlalu lama. Secara umum dapat disimpulkan, bahwa model arsitektur 4-8-1 dengan Bayesian regulation dapat digunakan untuk peramalan (prediksi) fenomena bencana alam di Indonesia, karena waktu perlatihan untuk pencapaian konvergensi tidak terlalu lama dan berkinerja cukup baik.
\end{abstract}

Kata kunci: ANN, bayesian regulation, kinerja, metode backpropagation, One-Step Secant.

\section{Pendahuluan}

Pemanfaatan fungsi transfer ataupun fungsi perlatihan hasilkan keakuratan peramalan yang berbeda-beda, tergantung kepada metode yang diberikan dan data terprediksi [1-5]. Pendekatan beberapa fungsi perlatihan pada Machine Learning berbasis ANN 
(jaringan syaraf tiruan, JST) dapat digunakan untuk gradient descent (traingd, traingdx, traingda dan penyelesaian masalah komputasi yang berhubungan traingdm) [23]. Fungsi perlatihan lain dapat digunakan dengan data peramalan atau prediksi [6]. Fungsi untuk optimasi dan berpengaruh terhadap hasil perlatihan pada teknik Machine Learning dengan ANN komputasi, seperti Levenberg-Marquardt (trainlm) metode backpropagation dapat dihasilkan keakuratan [24,25], perlatihan batch dengan aturan pembelajaran peramalan berbeda-beda, bergantung kepada parameter bobot dan bias (trainb) [26], BFGS quasi-Newton masukan dan data terprediksi. Teknik Machine (trainbfg) [27], BFGS quasi-Newton dengan referensi Learning berbasis ANN sangat populer dan sukses adaptif control (trainbfgc) [28], regulasi bayesian diimplementasikan pada berbagai bidang penelitian, (trainbr) [29], perlatihan batch bobot/bias tanpa seperti bisnis, kesehatan, teknologi, maupun pendidikan pengawasan (trainbu) [30], urutan siklus bobot/bias [7]. Selain hal itu, JST dapat digunakan untuk (trainc) [31], perlatihan konjugasi gradien (traincgf, penyelesaian masalah yang kompleks dengan tingkat traingcgp, traincgb) [32], One-Step Secant (garis kekomleksan tinggi [8-10], seperti jaringan saraf untuk potong satu langkah, trainoss) [33], perlatihan analisis gambar dan perlacakan objek maupun analisis tambahan urutan acak dengan fungsi pembelajaran data times-series [11].

Teknik Machine Learning dengan penyediaan metode untuk kemungkinan pembelajaran komputer secara otomatis tanpa campur tangan manusia [12] dan untuk penyesuaian terhadap tindakan yang tepat [13], karena (trainr) [34], resilient (trainrp) [35], perlatihan bobot/bias perintah acak tidak diawasi (trainru) [36], perlatihan urutan inkremental berurutan dengan fungsi pembelajaran (trains) [37], dan gradien konjugasi berskala (trainscg) [38].

Machine Learning berfokus peningkatan kinerja sistem Berdasarkan uraian terkait penelitian-penelitian pembelajaran secara otomatis melalui pengalaman [14]. sebelumnya, maka penelitian pada makalah ini berupa Masalah Machine Learning dapat dilihat sebagai salah analisis pemanfaatan fungsi perlatihan untuk optimasi satu cara untuk optimasi kinerja metode komputer keakuratan dan pengukuran kinerja pada Machine berdasarkan data sebelumnya [15]. Pemanfaatan fungsi Learning berbasis ANN untuk peramalan fenomena perlatihan untuk pemberian kinerja yang optimal, telah bencana alam di Indonesia. Makalah ini dengan digunakan secara luas dalam penyelesaian masalah pembahasan tentang metode fungsi perlatihan untuk dengan tingkat kekomplekan tinggi. Uwanuakwa and penyelesaian masalah, sedangkan dataset bencana alam Akpinar [38] dengan pembahasan tentang efisiensi hanya digunakan untuk bantuan pembuktian dan proses prediksi kedalaman karbonasi beton dengan optimasi pengukuran kinerja. Implementasi teknik Machine fungsi perlatihan metode One-Step Secant (OSS) Learning dengan metode backpropagation standar sebagai alternatif dari Levenberg-Marquardt sering kali dengan pemberian nilai kecepatan konvensional yang digunakan. Untuk prediksi konvergensi yang buruk pada proses perlatihan, karbonasi beton diperoleh nilai koefisien relasi (R) sehingga perlu dilakukan berbagai kombinasi fungsi sebesar 0,99 dengan variasi hasil persentase 30-55\% perlatihan untuk pemercepatan konvergensi perlatihan dengan arti, bahwa terdapat peningkatan nilai R secara jaringan syaraf, yakni dengan penggunaan metode Onesignifikan dari yang diamati sebesar 60-80\%. Selain hal Step Secant (OSS) dan Bayesian Regulation. itu, berdasarkan pengamatan ditunjukkan, bahwa Keakuratan dan kinerja dari metode backpropagation variasi neuron tersembunyi antara 5-25 dihasilkan standar dianalisis dan dibandingkan terhadap metode perubahan akurasi prediksi kurang signifikan, baik nilai One-Step Secant (OSS) dan Bayesian regulation yang $\mathrm{R}$, MSE, maupun persentasenya [16].

Metode backpropagation merupakan metode berbasis gradien yang banyak digunakan untuk perlatihan jaringan saraf feedforward (umpan maju) [17-19]. Perkembangan metode backpropagation dengan beberapa fungsi, diantaranya fungsi transfer dan perlatihan yang masing-masing fungsi juga dengan banyak teknik dan metode yang dapat digunakan untuk menyelesaikan penyelesaian masalah dengan tingkat kekompleksan yang tinggi. Penggunaan fungsi transfer pada Machine Learning berbasis jaringan saraf, khususnya backpropagation, yaitu fungsi transfer sigmoid tangen hiperbolik (tansig) [20], fungsi transfer log-sigmoid (logsig) [21], dan fungsi transfer linear (purelin) [22], sedangkan penggunaan fungsi perlatihan pada metode backpropagation standar, diantaranya merupakan pengembangan dari metode backpropagation. Tujuan penelitian ini untuk memperoleh optimasi keakuratan dan pengukuran Performance, sasaran penelitian berupa hasil pembandingan dari ketiga metode tersebut dalam pencarian hasil terbaik untuk pelaksanaan data peramalan fenomena bencana.

\section{Metode Penelitian}

\subsection{Bahan Penelitian}

Seperangkat data (dataset) penelitian untuk fungsi perlatihan berupa data times-series bencana alam di wilayah Indonesia pada kurun waktu 10 tahun terakhir (2011-2020) yang terdiri atas (i) putting-beliung, (ii) kebakaran hutan dan lahan, (iii) banjir, (iv) tanah longsor, (v) kekeringan, (vi) gempa bumi, (vii)

DOI: https://doi.org/10.29207/resti.v5i2.3031

Lisensi: Creative Commons Attribution 4.0 International (CC BY 4.0) 
gelombang pasang dan abrasi, dan (viii) erupsi gunung berapi. Data diperoleh dari Geoportal Kebencanaan Indonesia yang bersumber dari Badan Nasional Penganggulangan Bencana (BNPB) melalui menu infografis di website https://gis.bnpb.go.id/ [39]. Jenis bencana alam di Indoensia kurun waktu 2011-2020, seperti ditunjukkan pada Tabel 1 .

Tabel 1. Jenis bencana alam di Indonesia (kurun waktu 2011-2020)

\begin{tabular}{lrrrr}
\hline \multirow{2}{*}{\multicolumn{1}{c}{ Jenis Bencana }} & \multicolumn{5}{c}{ Tahun } \\
\cline { 2 - 6 } & 2011 & 2012 & $\ldots$ & 2020 \\
\hline Putting-beliung & 320 & 543 & $\ldots$ & 880 \\
Kebakaran hutan dan lahan & 376 & 58 & $\ldots$ & 326 \\
Banjir & 403 & 581 & $\ldots$ & 1080 \\
Tanah longsor & 261 & 287 & $\ldots$ & 577 \\
Kekeringan & 221 & 263 & $\ldots$ & 29 \\
Gempa bumi & 11 & 12 & $\ldots$ & 16 \\
Gelombang pasang dan abrasi & 16 & 29 & $\ldots$ & 36 \\
Erupsi gunung berapi & 11 & 7 & $\ldots$ & 7 \\
Total Bencana & 1619 & 1780 & $\ldots$ & 2951 \\
\hline
\end{tabular}

Tampilan infografis bencana di Indonesia tahun 2020, seperti ditunjukkan pada Gambar 1.

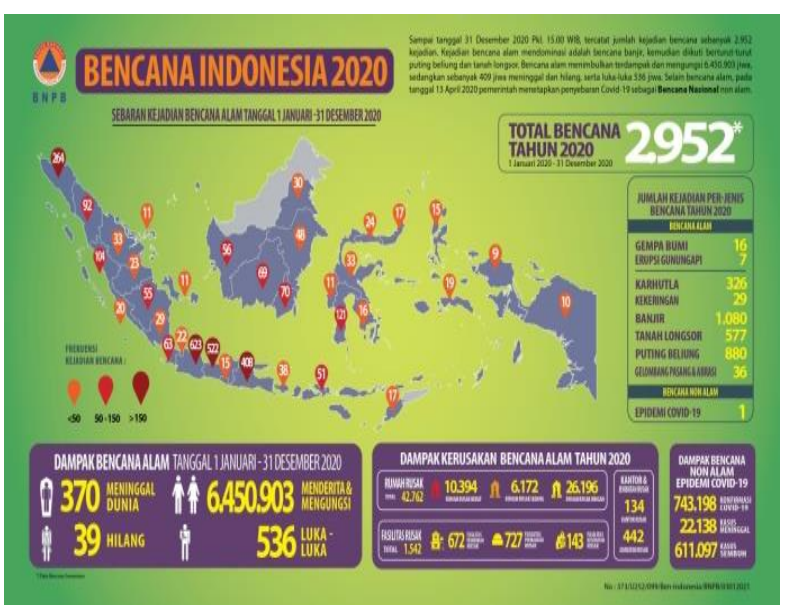

Gambar 1. Tampilan infografis bencana di Indonesia tahun 2020

Berdasarkan Gambar 1 dapat dijelaskan, bahwa informasi bencana alam di Indonesia pada tahun 2020 dengan total bencana sebanyak 2951, ditambah 1 bencana non-alam, yakni Covid-19. Bencana alam banjir dengan kejadian terbesar, diikuti bencana putingbeliung dan tanah longsor. Dampak bencana alam sepanjang 1 Januari sampai 31 Desember 2020, meliputi korban jiwa meninggal dunia sebanyak 370, 6.450.903 menderita dan mengungsi, 39 hilang, dan 536 luka-luka.

\subsection{Metode Penelitian}

Metode penelitian merupakan algoritma seorang peneliti dalam pelaksanaan penelitian secara keseluruhan. Diagram Alir metode penelitian, seperti ditunjukkan pada Gambar 2.

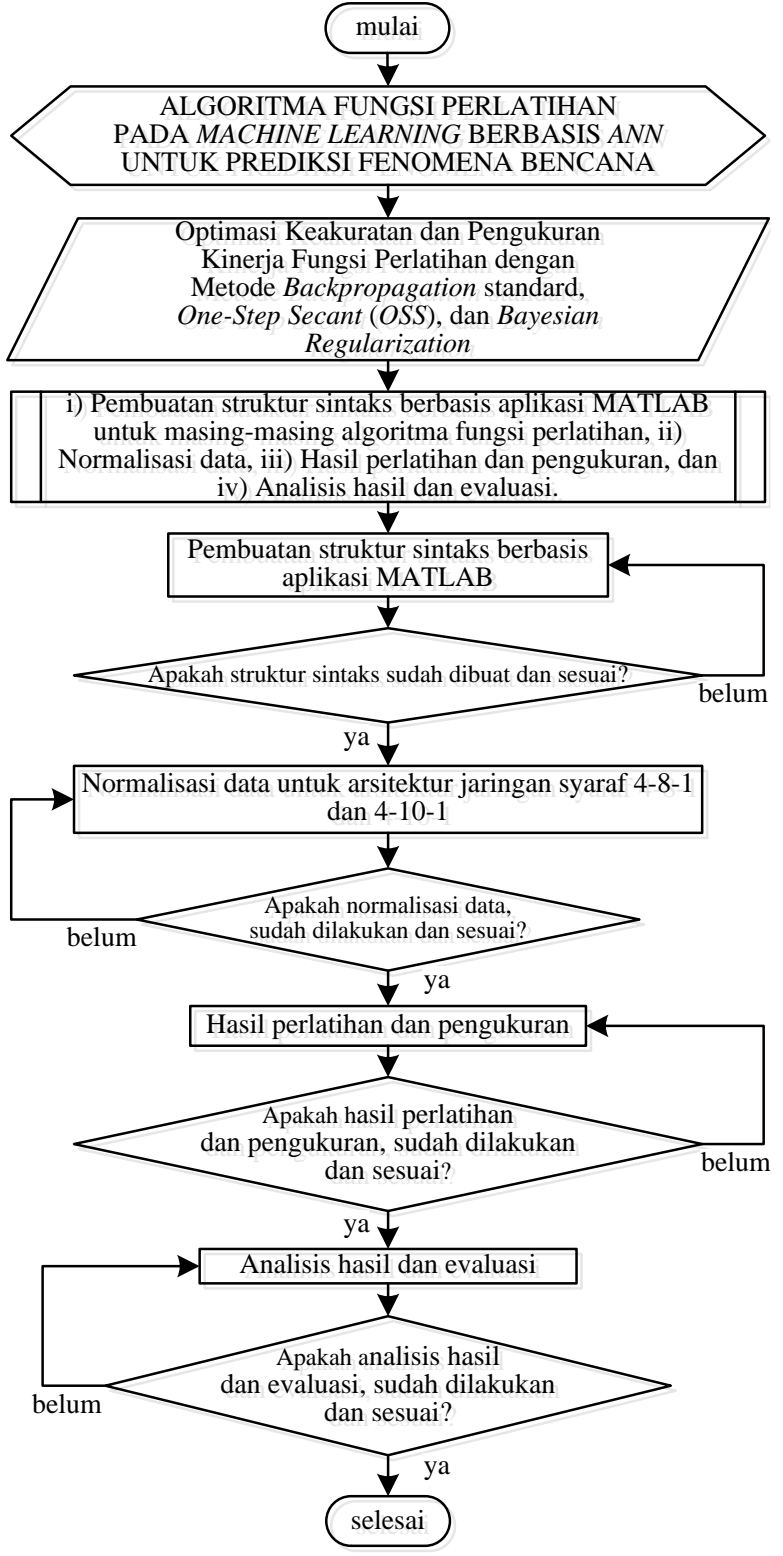

Gambar 2. Diagram alir metode penelitian

Berdasarkan Gambar 2 dapat dijelaskan, bahwa langkah pertama dalam tahapan penelitian berupa pengumpulan seperangkat data (dataset) penelitian, sebagaimana ditunjukkan pada Tabel 1. Langkah berikutnya berupa pemisahan dataset penelitian menjadi 2 kelompok, yakni untuk data perlatihan dan pengukuran kinerja. Data perlatihan berdasarkan data bencana tahun 2011-2014 (X1-X4) dengan target perlatihan tahun 2015 (Y1), sedangkan untuk data pengukuran kinerja berdasarkan data tahun 2016-2019 (X5-X8) dengan target pengukuran kinerja tahun 2020 (Y2). Tahapan selanjutnya berupa pelaksanaan normalisasi data perlatihan dan pengukuran kinerja dengan penggunaan persamaan (1) [40].

DOI: https://doi.org/10.29207/resti.v5i2.3031

Lisensi: Creative Commons Attribution 4.0 International (CC BY 4.0) 


$$
x^{\prime}=\frac{0.8(\mathrm{x}-\mathrm{a})}{\mathrm{b}-\mathrm{a}}+0.1
$$

(1) $>$ net. $b\{1\}$;

(1) $>$ net. $L W\{2,1\}$;

$>$ net. $\{\{2\}$

dengan: $x^{\prime}=$ hasil data setelah dinormalisasi, nilai $0,8 \% \mathrm{Ni} 1 \mathrm{ai}$ metode backpropagation

dan 0,1 merupakan nilai default dari persamaan $\rightarrow$ net. trainparam.epochs $=5000$;

normalisasi, $\mathrm{x}$ merupakan data target untuk dinormalisasi, $\mathrm{a}=$ nilai terendah dari dataset dan $\mathrm{b}=$ nilai tertinggi dari dataset.

Data perlatihan setelah dinormalisasi dimasukkan ke dalam aplikasi MATLAB versi 2011b untuk diproses, dilanjutkan dengan pembuatan jaringan saraf multi layer. Model arsitektur jaringan syaraf untuk proses perlatihan pada penelitian ini adalah 4-8-1 dan 4-10-1 (4 merupakan input layer, 8 dan 10 merupakan hidden layer dengan 8 dan 10 neuron, 1 merupakan output layer). Pembuatan jaringan syaraf multi layer ini, Struktur sintaks untuk metode One-Step Secant, yaitu: hidden layer digunakan fungsi transfer logsig (sigmoid biner) dan output layer digunakan purelin (fungsi linear). Tahapan ini juga dilakukan pemilihan fungsi perlatihan, dengan masing-masing data perlatihan bergantian dilatih dengan penggunaan fungsi perlatihan penurunan gradien (traingd) pada backpropagation standard, kemudian dioptimasi dengan metode fungsi perlatihan metode One-Step Secant (trainoss) dan Bayesian regulation (trainbr). Tahapan lanjutan berupa pembangkitan nilai bobot (IW, LW) dan bias (b). Tahapan inisialisasi parameter jaringan syaraf berdasarkan fungsi perlatihan yang digunakan, kemudian dimasukkan perintah untuk pelaksanaan proses perlatihan dan diperiksa hasil saat kinerja (Performance) ditemukan. Untuk kondisi dimana hasil perlatihan tercapai konvergensi, maka dilanjutkan dengan pemasukan data pengukuran yang sudah dinormalisasi, sedangkan jika hasil perlatihan belum tercapai konvergensi, maka kembali ke tahap pembuatan MLNN dan pemilihan fungsi perlatihan. Tahapan dilanjutkan dengan simulasi data ukur berdasarkan hasil perlatihan, apabila semua sudah dilakukan, tahapan akhir berupa evaluasi untuk pemeriksaan kinerja dan kemampuan algoritma fungsi perlatihan terbaik.

\section{Hasil dan Pembahasan}

\subsection{Metode Fungsi Perlatihan}

Secara umum, masing-masing metode fungsi perlatihan pada penelitian ini diproses dengan aplikasi MATLAB versi 2011b. Struktur sintaks untuk metode backpropagation standar, yaitu:

\begin{tabular}{l}
\hline Metode "Backpropagation Standar" \\
\hline \% Dimasukkan Data Training \\
\% Dimasukkan Data Input \\
>> p=[Data per7atihan te7ah dinorma7isasi] \\
\% Dimasukkan Data output Target \\
>> t=[Target Data per7atihan] \\
>> net = newff(minmax(p), [hidden 7ayer, output \\
7ayer], \{'7ogsig', 'pure7in'\}, 'traingd'); \\
\% Dibangkitkan bobot dan bias \\
>> net.IW $\{1,1\} ;$
\end{tabular}

$\rightarrow$ net. trainparam. goa $7=0.001$;

$\gg$ net. trainparam. $7 r=0.01$

\% Dilakukan Training

$\rightarrow$ net $=\operatorname{train}($ net $, p, t)$

\% Dilihat hasil pada saat Performance

ditemukan

$\rightarrow[a, P f, A f, e, p e r f]=\operatorname{sim}($ net $, p,[],[], t)$

\% Dimasukkan Data Input (Ukur)

$\rightarrow p 1=[$ Data uji yang telah dinormalisasi]

Dimasukkan Data Target (ukur kinerja)

$>t 1=[$ Target Data Ukur]

\% Dilakukan simulasi penggunaan data ukur

berdasarkan hasil training

$\gg[a, p f, A f, e, p e r f]=\operatorname{sim}($ net $p 1,[],[], t 1)$

Metode One-step Secant (oss)

\% Dimasukkan Data Training

\% Dimasukkan Data Input

$\rightarrow p=[$ Data perlatihan telah dinormalisasi]

\% Dimasukkan Data output Target

$\rightarrow t=$ [Target data perlatihan]

$>$ net $=$ newff(minmax $(p)$, [hidden 7ayer, output

7ayer], \{'7ogsig', 'pure7in'\}, 'trainoss');

\% Dibangkitkan bobot dan biás

$\rightarrow$ net. IW $\{1,1\}$;

$\gg$ net. $b\{1\}$ :

$\gg$ net. $L W\{2,1\}$;

$\gg$ net. $b\{2\}$

$\%$ Nilai metode one-step secant

$\rightarrow$ net. trainparam. epochs $=5000$

$\gg$ net. trainparam. show $=25$;

$\gg$ net. trainparam. showcommand $\mathrm{ine}=0$;

$\gg$ net. trainparam. showwindow = 1;

$>$ net. trainparam.goa $7=0 ;$

$\gg$ net. trainparam.time = inf:

$\gg$ net. trainparam. min_grad $=1 e-6$;

$\gg$ net.trainparam. max_fai $7=5$;

> net. trainparam. searchFcn = 'srchcha';

\% Dilakukan Training

$\rightarrow$ net $=\operatorname{train}(n e t, p, t)$

Diperiksa hasil pada saat Performance

ditemukan

$\rightarrow[a, P f, A f, e, P e r f]=\operatorname{sim}(n e t, p,[],[], t)$

\% Dimasukkan Data Input (Ukur kinerja)

$>p 1=$ [Data uji yang telah dinorma7isasi]

\% Dimasukkan Data Target (ukur kinerja)

$\rightarrow$ t1=[Target data uji]

\% Dilakukan simulasi penggunaan data ukur

kinerja berdasarkan hasi1 training

$\rightarrow[a, p f, A f, e, p e r f]=\operatorname{sim}($ net $, p 1,[],[], t 1)$

Struktur sintaks untuk metode Bayesian Regulation, yaitu:

Metode Bayesian Regulation

\% Dimasukkan Data Training

\% Dimasukkan Data Input

$\gg p=$ [Data per7atihan telah dinorma7isasi]

\% Dimasukkan Data output Target

$\rightarrow t=[$ Target data perlatihan]

$\rightarrow$ net $=$ newff(minmax $(p)$, [hidden 7ayer, output

7ayer], \{'7ogsig', 'pure7in'\}, 'trainbr').

\% Dibangkitkan bobot dan bias

$>$ net. IW $\{1,1\}$;

$\rightarrow$ net. $\{\{1\}$

$\gg$ net. $L W\{2,1\}$;

$\rightarrow$ net.b $\{2\}$

\% Nilai metode Bayesian Regulation

$>$ net. trainparam. epochs=5000;

> net. trainparam. $m u=0.005$; $\rightarrow$ net. trainparam. show = 1000;

$\rightarrow$ net. trainparam.goa $7=0$; 
$\gg$ net.trainparam. mu_dec=0.1;

$\gg$ net. trainparam. mu_inc $=10$;

$>$ net.trainParam.mu_max=1e10;

> net. trainparam. max_fai 7=5;

$\gg$ net. trainparam.mem_reduc $=1$;

$\rightarrow$ net. trainParam.min_grad=1e-10;

$\rightarrow$ net. trainparam. show $=25$;

$>$ net. trainparam. showcommand ine=0;

$>$ net. trainparam. showwindow=1;

$\rightarrow$ net. trainparam.time=inf:

\% Dilakukan Training

$\rightarrow$ net $=\operatorname{train}($ net $, p, t)$

\% Diperiksa hasil pada saat Performance ditemukan

$\rightarrow[a, P f, A f, e$, perf $]=\operatorname{sim}($ net $, p,[],[], t)$

$\%$ memasukan data Input (Ukur kinerja)

> p1=[Data ukur kinerja telah dinorma7isasi]

\% Dimasukkan Dta Target (ukur kinerja)

$\rightarrow t 1=[$ Target data ukur kinerja]

\% Dilakukan simulasi penggunaan data ukur

kinerja berdasarkan hasil training

$\gg[a, P f, A f, e$, Perf $]=\operatorname{sim}($ net $, p 1,[],[], t 1)$

3.2. Normalisasi Data Untuk Perlatihan dan Pengukuran Kinerja

Data bencana alam di Indonesia (berdasarkan Tabel 1), terlebih dahulu dinormalisasi dengan penggunaan persamaan (1). Dataset penelitian dibagi menjadi dua bagian, yakni perlatihan dan pengukuran kinerja. Data untuk perlatihan berdasarkan dataset fenomena bencana tahun 2011-2014 (X1-X4) dengan tahun 2015 (Y1) sebagai target perlatihan. Hasil normalisasi data untuk perlatihan, seperti ditunjukkan pada Tabel 2 .

Tabel 2. Hasil normalisasi data untuk perlatihan

\begin{tabular}{cccccc}
\hline No. & X1 & X2 & X3 & X4 & Target (Y1) \\
\hline 1 & 0,4574 & 0,7105 & 0,6617 & 0,7956 & 0,7423 \\
2 & 0,5210 & 0,1601 & 0,1363 & 0,2191 & 0,1511 \\
3 & 0,5516 & 0,7536 & 0,9000 & 0,7616 & 0,6878 \\
4 & 0,3905 & 0,4200 & 0,4268 & 0,7729 & 0,6640 \\
5 & 0,3451 & 0,3928 & 0,1692 & 0,1023 & 0,1023 \\
6 & 0,1068 & 0,1079 & 0,1125 & 0,1091 & 0,1227 \\
7 & 0,1125 & 0,1272 & 0,1352 & 0,1193 & 0,1023 \\
8 & 0,1068 & 0,1023 & 0,1034 & 0,1000 & 0,1045 \\
\hline
\end{tabular}

Data pengukuran kinerja didasarkan kepada data tahun 2016-2019 sebagai X5-X8 dengan target ukur kinerja tahun 2020 sebagai Y2. Hasil normalisasi data untuk ukur kinerja, seperti ditunjukkan pada Tabel 3.

Tabel 3. Hasil normalisasi data untuk ukur kinerja

\begin{tabular}{cccccc}
\hline No. & X5 & X6 & X7 & X8 & Target (Y2) \\
\hline 1 & 0,4806 & 0,6104 & 0,7413 & 0,9000 & 0,6063 \\
2 & 0,2002 & 0,1521 & 0,4018 & 0,5287 & 0,2854 \\
3 & 0,5715 & 0,6636 & 0,6011 & 0,5507 & 0,7222 \\
4 & 0,4429 & 0,5878 & 0,4528 & 0,5130 & 0,4308 \\
5 & 0,1006 & 0,1075 & 0,1840 & 0,1678 & 0,1133 \\
6 & 0,1023 & 0,1081 & 0,1127 & 0,1139 & 0,1058 \\
7 & 0,1093 & 0,1029 & 0,1162 & 0,1070 & 0,1174 \\
8 & 0,1006 & 0,1000 & 0,1301 & 0,1006 & 0,1006 \\
\hline
\end{tabular}

\subsection{Hasil Perlatihan dan Pengukuran Kinerja}

Perlatihan dan pengukuran kinerja dilakukan dengan penggunaan aplikasi MATLAB versi 2011 b dengan 2 model arsitektur jaringan, yakni 4-8-1 dan 4-10-1.
\#1) Perlatihan dan pengukuran kinerja dengan metode backpropagation standar

@ 1.a) Jaringan syaraf model arsitektur 4-8-1

Tampilan hasil perlatihan terhadap model arsitektur 48-1 (traingd), seperti ditunjukkan pada Gambar 3.

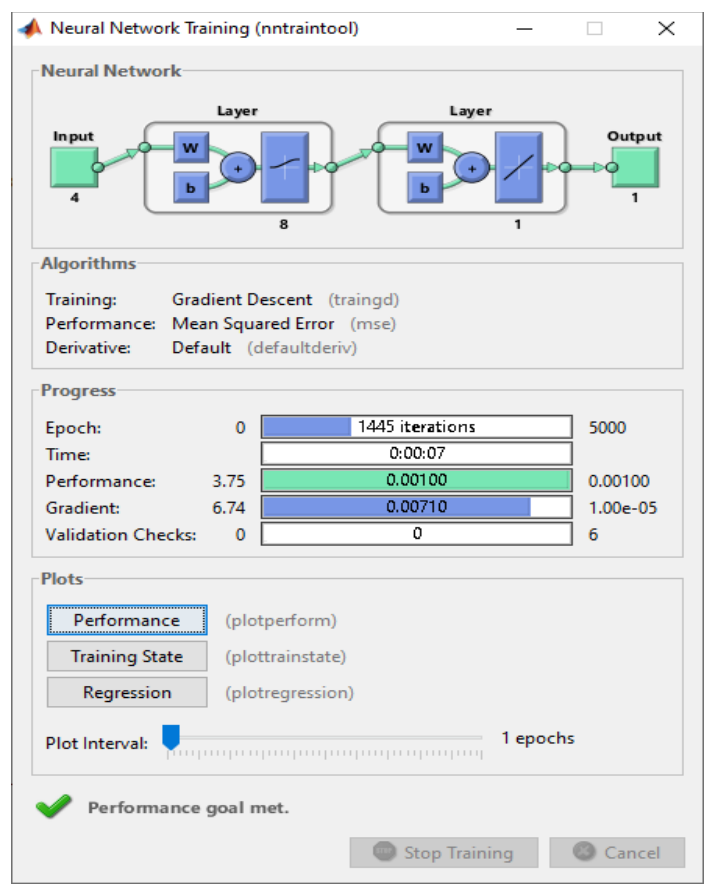

Gambar 3. Perlatihan Model 4-8-1 (traingd)

Gambar 3 menjelaskan bahwa hasil perlatihan dengan penggunaan fungsi traingd pada model 4-8-1 dihasilkan epoch sebesar 1445 iterasi dengan waktu latih selama 7 detik.

Hasil perlatihan terhadap model arsitekstur 4-8-1 (traingd), seperti ditunjukkan pada Tabel 4.

Tabel 4. Hasil Perlatihan Model Arsitektur 4-8-1 (traingd)

\begin{tabular}{ccccc}
\hline \multirow{2}{*}{ Target (Y1) } & \multicolumn{4}{c}{ Epoch 1445} \\
\cline { 2 - 4 } & Actual & Error & SSE & Performance \\
\hline 0,7423 & 0,7254 & 0,0169 & 0,00028458 & \\
0,1511 & 0,1088 & 0,0423 & 0,00178623 & \\
0,6878 & 0,7013 & $-0,0135$ & 0,00018221 & \\
0,6640 & 0,6727 & $-0,0087$ & 0,00007618 & 0 \\
0,1023 & 0,1734 & $-0,0711$ & 0,00505955 & \multirow{2}{*}{00099981} \\
0,1227 & 0,0989 & 0,0238 & 0,00056620 & \\
0,1023 & 0,0992 & 0,0031 & 0,00000942 & \\
0,1045 & 0,0987 & 0,0058 & 0,00003409 & \\
\cline { 2 - 4 } & & Total SSE & 0,00799847 & \\
\cline { 3 - 4 } & & MSE & 0,00099981 &
\end{tabular}

Berdasarkan Tabel 4 dapat dijelaskan, bahwa hasil perlatihan dengan model arsitektur 4-8-1 dengan nilai konvergensi pada iterasi ke 1445 dengan nilai Performance sebesar 0,00099981.

Hasil pengukuran kinerja terhadap model arsitektur 48-1 (traingd), seperti ditunjukkan pada Tabel 5. 
Tabel 5. Hasil pengukuran kinerja terhadap arsitektur jaringan syaraf 4-8-1 (traingd)

\begin{tabular}{ccccc}
\hline \multirow{2}{*}{ Target (Y2) } & \multicolumn{4}{c}{ Epoch 1} \\
\cline { 2 - 4 } & Actual & Error & SSE & Performance \\
\hline 0,6063 & 0,7669 & $-0,1606$ & 0,025792430 & \\
0,2854 & 0,1206 & 0,1648 & 0,027150115 & \\
0,7222 & 0,1543 & 0,5679 & 0,322462545 & \\
0,4308 & 0,7923 & $-0,3615$ & 0,130700470 & 0,063334482 \\
0,1133 & 0,0999 & 0,0134 & 0,000180195 & \\
0,1058 & 0,0990 & 0,0068 & 0,000046144 & \\
0,1174 & 0,0989 & 0,0185 & 0,000341463 & \\
0,1006 & 0,0990 & 0,0016 & 0,000002494 & \\
\cline { 2 - 3 } & & Total SSE & 0,506675855 & \\
\cline { 3 - 4 } & & MSE & 0,063334482 &
\end{tabular}

Berdasarkan Tabel 5 dapat dijelaskan, bahwa nilai Performance diperoleh sebesar 0,063334482.

Nilai aktual pada Tabel 4 dan Tabel 5 diperoleh dari keluaran hasil perlatihan dan pengukuran kinerja. Nilai error diperoleh dari perhitungan Target (Y). Nilai aktual SSE diperoleh berdasarkan perhitungan error dikuadratkan (error ${ }^{\wedge}$ ). Nilai total SSE diperoleh dari penjumlahan nilai $S S E$ secara keseluruhan, sedangkan nilai Performance (Perf) diperoleh dari total SSE dibagi 8 , dengan 8 merupakan jumlah baris data. Berdasarkan hasil perlatihan dan pengukuran kinerja dengan penggunaan aplikasi MATLAB dan Ms. Excel, terdapat kesesuaian (valid).

@ 1.b) Jaringan syaraf model arsitektur 4-10-1

Tampilan hasil perlatihan terhadap model arsitektur 410-1 (traingd), seperti ditunjukkan pada Gambar 4.

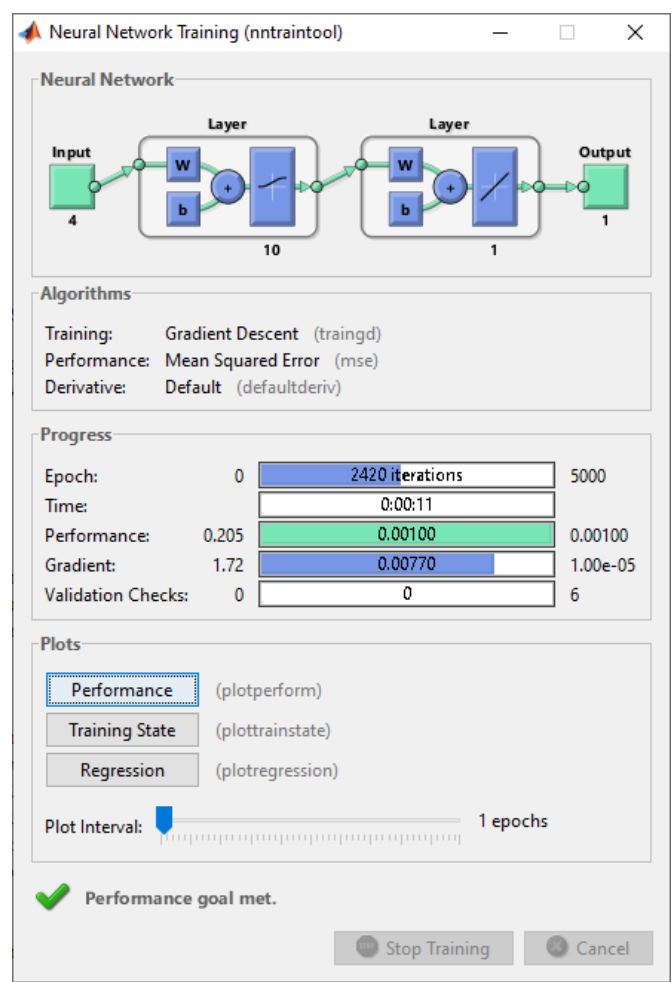

Gambar 4. Tampilan hasil perlatihan terhadap model arsitektur 4-10-1 (traingd)
Berdasarkan Gambar 4 dapat dijelaskan, bahwa hasil perlatihan dengan penggunaan fungsi traingd pada model 4-8-1 dihasilkan epoch sebesar 2420 iterasi dengan waktu latih selama 11 detik.

Hasil perlatihan terhadap model arsitekstur 4-10-1 (traingd), seperti ditunjukkan pada Tabel 6 .

Tabel 6. Hasil Perlatihan Model Arsitektur 4-10-1 (traingd)

\begin{tabular}{|c|c|c|c|c|}
\hline \multirow{2}{*}{ Target (Y1) } & \multicolumn{4}{|c|}{ Epoch 2420} \\
\hline & Actual & Error & SSE & Performance \\
\hline 0,7423 & 0,7615 & $-0,0192$ & 0,00036981 & \multirow{8}{*}{0,00100007} \\
\hline 0,1511 & 0,1870 & $-0,0359$ & 0,00129141 & \\
\hline 0,6878 & 0,7029 & $-0,0151$ & 0,00022797 & \\
\hline 0,6640 & 0,6131 & 0,0509 & 0,00258792 & \\
\hline 0,1023 & 0,0537 & 0,0486 & 0,00235900 & \\
\hline 0,1227 & 0,1171 & 0,0056 & 0,00003130 & \\
\hline 0,1023 & 0,1354 & $-0,0331$ & 0,00109763 & \\
\hline \multirow[t]{3}{*}{0,1045} & 0,1105 & $-0,0060$ & 0,00003553 & \\
\hline & & Total SSE & 0,00800057 & \\
\hline & & MSE & 0,00100007 & \\
\hline
\end{tabular}

Berdasarkan Tabel 6 dapat dijelaskan, bahwa hasil perlatihan dengan model arsitektur 4-10-1 dengan nilai konvergensi pada iterasi ke 2420 dengan nilai Performance sebesar 0,00100007.

Hasil pengukuran kinerja terhadap model arsitektur 410-1 (traingd), seperti ditunjukkan pada Tabel 7.

Tabel 7. Hasil pengukuran kinerja terhadap arsitektur jaringan syaraf 4-10-1 (traingd)

\begin{tabular}{ccccc}
\hline \multirow{2}{*}{ Target (Y2) } & \multicolumn{4}{c}{ Epoch 1} \\
\cline { 2 - 5 } & Actual & Error & SSE & Performance \\
\hline 0,6063 & 0,8151 & $-0,2088$ & 0,043597531 & \\
0,2854 & 0,3217 & $-0,0363$ & 0,001319657 & \\
0,7222 & 0,5990 & 0,1232 & 0,015167858 & \\
0,4308 & 0,6052 & $-0,1744$ & 0,030424150 & 0,011395198 \\
0,1133 & 0,1193 & $-0,0060$ & 0,000035716 & \\
0,1058 & 0,1202 & $-0,0144$ & 0,000207564 & \\
0,1174 & 0,1105 & 0,0069 & 0,000047317 & \\
0,1006 & 0,1196 & $-0,0190$ & 0,000361787 & \\
& & Total SSE & 0,091161580 & \\
\cline { 3 - 4 } & & MSE & 0,011395198 \\
\cline { 3 - 4 }
\end{tabular}

Berdasarkan Tabel 7 dapat dijelaskan, bahwa nilai Performance diperoleh sebesar 0,011395198.

Nilai aktual pada Tabel 6 dan Tabel 7 diperoleh dari keluaran hasil perlatihan dan pengukuran kinerja. Nilai aktual SSE diperoleh berdasarkan perhitungan error dikuadratkan $\left(\operatorname{error}^{\wedge} 2\right)$. Nilai total SSE diperoleh dari penjumlahan nilai $S S E$ secara keseluruhan, sedangkan nilai Performance (Perf) diperoleh dari total SSE dibagi 8 , dengan 8 merupakan jumlah baris data. Berdasarkan hasil perlatihan dan pengukuran kinerja dengan penggunaan aplikasi MATLAB dan Ms. Excel, terdapat kesesuaian (valid).

@ 2.a) Jaringan syaraf model arsitektur 4-8-1

Tampilan hasil perlatihan terhadap model arsitektur 48-1 (trainoss), seperti ditunjukkan pada Gambar 5.

DOI: https://doi.org/10.29207/resti.v5i2.3031

Lisensi: Creative Commons Attribution 4.0 International (CC BY 4.0) 


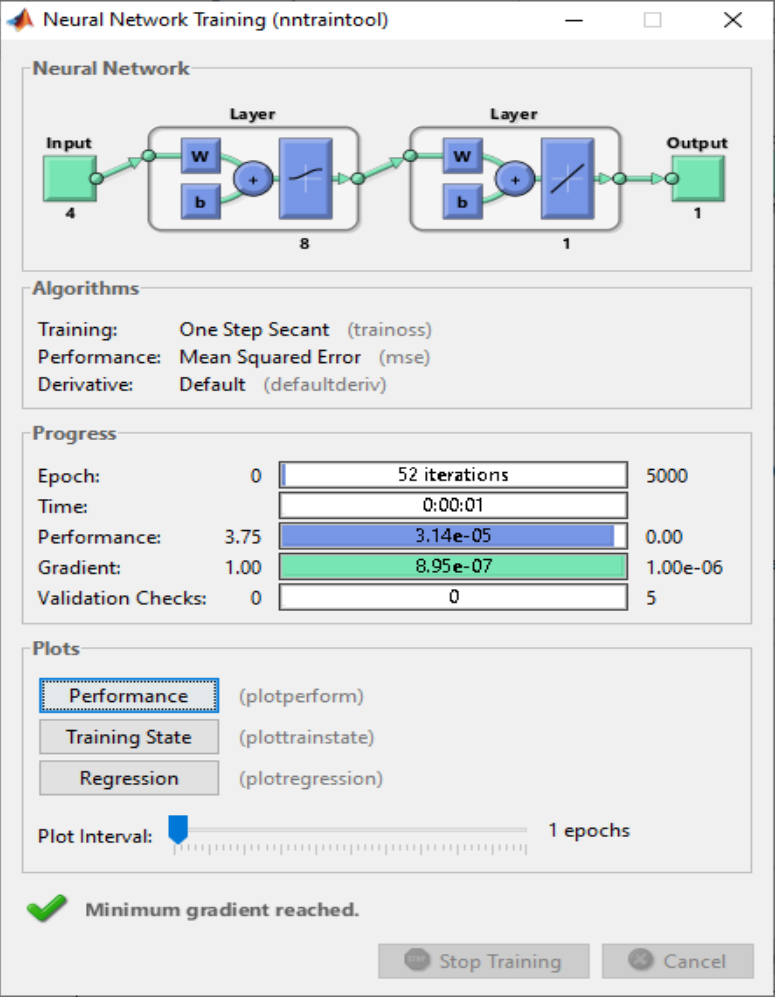

Gambar 5. Perlatihan Model 4-8-1 (trainoss)

Berdasarkan Gambar 5 dapat dijelaskan, bahwa hasil perlatihan dengan penggunaan fungsi trainoss pada model 4-8-1 dihasilkan epoch sebesar 52 iterasi dengan waktu latih selama 1 detik.

Hasil perlatihan terhadap model arsitekstur 4-8-1 (trainoss), seperti ditunjukkan pada Tabel 8.

Tabel 8. Hasil Perlatihan Model Arsitektur 4-8-1 (trainoss)

\begin{tabular}{ccccc}
\hline \multirow{2}{*}{ Target (Y1) } & \multicolumn{4}{c}{ Epoch 52 } \\
\cline { 2 - 4 } & Actual & Error & SSE & Performance \\
\hline 0,7423 & 0,7423 & 0,0000 & 0,00000000 & \\
0,1511 & 0,1511 & 0,0000 & 0,00000000 & \\
0,6878 & 0,6878 & 0,0000 & 0,00000000 & \\
0,6640 & 0,6640 & 0,0000 & 0,00000000 & 0,00003121 \\
0,1023 & 0,1023 & 0,0000 & 0,00000000 & \\
0,1227 & 0,1099 & 0,0128 & 0,00016371 & \\
0,1023 & 0,1101 & $-0,0078$ & 0,00006132 & \\
0,1045 & 0,1095 & $-0,0050$ & 0,00002461 & \\
\cline { 2 - 3 } & & Total SSE & 0,00024965 & \\
\cline { 3 - 4 } & & MSE & 0,00003121 &
\end{tabular}

Berdasarkan Tabel 8 dapat dijelaskan, bahwa hasil perlatihan dengan model arsitektur 4-8-1 dengan nilai konvergensi pada iterasi ke 52 dengan nilai Performance sebesar 0,00003121.

Hasil pengukuran kinerja terhadap model arsitektur 48-1 (trainoss), seperti ditunjukkan pada Tabel 9.

Berdasarkan Tabel 9 dapat dijelaskan, bahwa nilai Performance diperoleh sebesar 0,060843522.
Tabel 9. Hasil pengukuran kinerja terhadap arsitektur jaringan syaraf 4-8-1 (trainoss)

\begin{tabular}{|c|c|c|c|c|}
\hline \multirow{2}{*}{ Target (Y2) } & \multicolumn{4}{|c|}{ Epoch 1} \\
\hline & Actual & Error & SSE & Performance \\
\hline 0,6063 & 0,8029 & $-0,1966$ & 0,038651645 & \multirow{8}{*}{0,060843522} \\
\hline 0,2854 & 0,2384 & 0,0470 & 0,002206455 & \\
\hline 0,7222 & 0,1242 & 0,5980 & 0,357553598 & \\
\hline 0,4308 & 0,7277 & $-0,2969$ & 0,088164574 & \\
\hline 0,1133 & 0,1130 & 0,0003 & 0,000000105 & \\
\hline 0,1058 & 0,1102 & $-0,0044$ & 0,000019422 & \\
\hline 0,1174 & 0,1099 & 0,0075 & 0,000055931 & \\
\hline \multirow[t]{3}{*}{0,1006} & 0,1104 & $-0,0098$ & 0,000096446 & \\
\hline & & Total SSE & 0,486748177 & \\
\hline & & MSE & 0,060843522 & \\
\hline
\end{tabular}

Nilai aktual pada Tabel 8 dan Tabel 9 diperoleh dari keluaran hasil perlatihan dan pengukuran kinerja. Nilai error diperoleh dari perhitungan Target (Y). Nilai aktual $S S E$ diperoleh berdasarkan perhitungan error dikuadratkan $\left(\operatorname{error}^{\wedge} 2\right)$. Nilai total $S S E$ diperoleh dari penjumlahan nilai $S S E$ secara keseluruhan, sedangkan nilai Performance (Perf) diperoleh dari total SSE dibagi 8 , dengan 8 merupakan jumlah baris data. Berdasarkan hasil perlatihan dan pengukuran kinerja dengan penggunaan aplikasi MATLAB dan Ms. Excel, terdapat kesesuaian (valid).

@2.b) Jaringan syaraf model arsitektur 4-10-1

Tampilan hasil perlatihan terhadap model arsitektur 410-1 (trainoss), seperti ditunjukkan pada Gambar 6

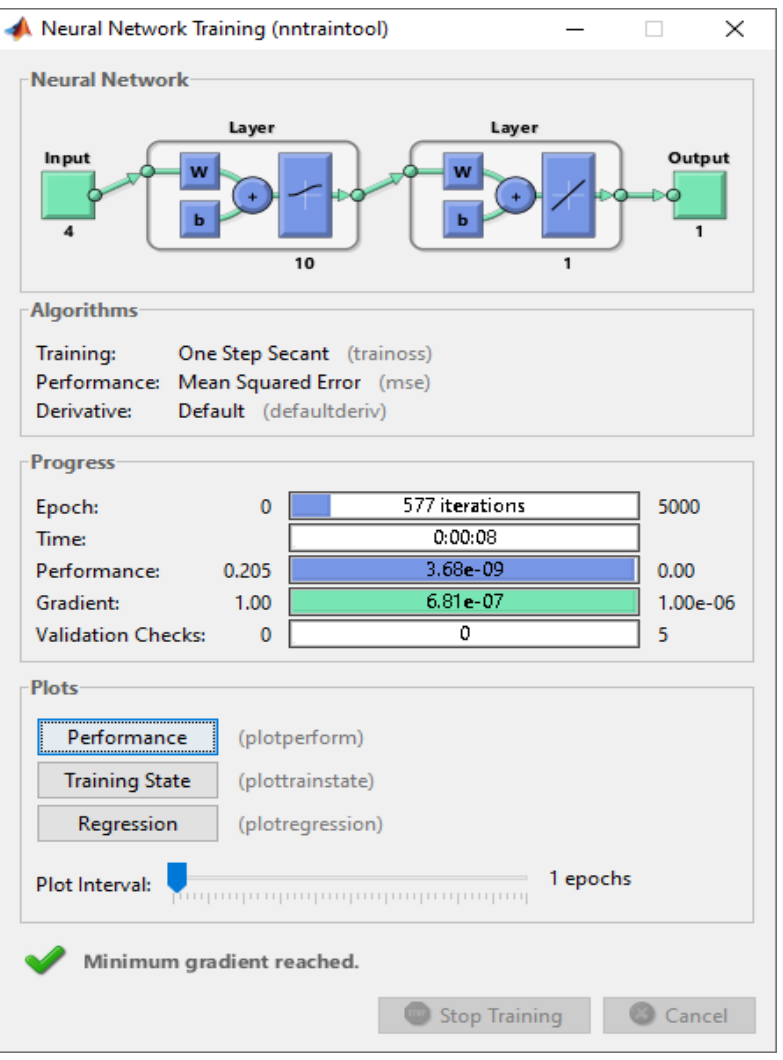

Gambar 6. Perlatihan Model 4-10-1 (trainoss) 
Berdasarkan Gambar 6 dapat dijelaskan, bahwa hasil @3.a) Jaringan syaraf model arsitektur 4-8-1 perlatihan dengan penggunaan fungsi trainoss pada Tampilan hasil perlatihan terhadap model arsitektur 4model 4-10-1 dihasilkan epoch sebesar 577 iterasi 8-1 (trainbr), seperti ditunjukkan pada Gambar 7. dengan waktu latih selama 8 detik.

Hasil perlatihan terhadap model arsitekstur 4-10-1 (trainoss), seperti ditunjukkan pada Tabel 10.

Tabel 10. Hasil Perlatihan Model Arsitektur 4-10-1 (trainoss)

\begin{tabular}{|c|c|c|c|c|}
\hline \multirow{2}{*}{ Target (Y1) } & \multicolumn{4}{|c|}{ Epoch 577} \\
\hline & Actual & Error & SSE & Performance \\
\hline 0,7423 & 0,7423 & 0,0000 & 0,00000000 & \multirow{8}{*}{0,0000000042} \\
\hline 0,1511 & 0,1511 & 0,0000 & 0,00000000 & \\
\hline 0,6878 & 0,6878 & 0,0000 & 0,00000000 & \\
\hline 0,6640 & 0,6640 & 0,0000 & 0,00000000 & \\
\hline 0,1023 & 0,1023 & 0,0000 & 0,00000000 & \\
\hline 0,1227 & 0,1226 & 0,0001 & 0,00000001 & \\
\hline 0,1023 & 0,1024 & $-0,0001$ & 0,00000002 & \\
\hline \multirow[t]{2}{*}{0,1045} & 0,1046 & $-0,0001$ & 0,00000000 & \\
\hline & & Total SSE & 0,00000003 & \\
\hline
\end{tabular}

Berdasarkan Tabel 10 dapat dijelaskan, bahwa hasil perlatihan dengan model arsitektur 4-10-1 dengan nilai konvergensi pada iterasi ke 577 dengan nilai Performance sebesar 0,0000000042.

Hasil pengukuran kinerja terhadap model arsitektur 410-1 (trainoss), seperti ditunjukkan pada Tabel 11.

Tabel 11. Hasil pengukuran kinerja terhadap arsitektur jaringan syaraf 4-10-1 (trainoss)

\begin{tabular}{ccccc}
\hline \multirow{2}{*}{ Target (Y2) } & \multicolumn{4}{c}{ Epoch 1} \\
\cline { 2 - 4 } & Actual & Error & SSE & Performance \\
\hline 0,6063 & 0,8594 & $-0,2531$ & 0,064059720 & \\
0,2854 & 1,5691 & $-1,2837$ & 1,647955221 & \\
0,7222 & 0,5691 & 0,1531 & 0,023426707 & \\
0,4308 & 0,5244 & $-0,0936$ & 0,008765678 & 0,231618030 \\
0,1133 & 0,4233 & $-0,3100$ & 0,096085320 & \\
0,1058 & 0,1498 & $-0,0440$ & 0,001936625 & \\
0,1174 & 0,1343 & $-0,0169$ & 0,000286330 & \\
0,1006 & 0,2027 & $-0,1021$ & 0,010428639 & \\
\cline { 2 - 3 } & & Total SSE & 1,852944240 & \\
\cline { 3 - 4 } & & MSE & 0,231618030 &
\end{tabular}

Berdasarkan Tabel 11 dapat dijelaskan, bahwa nilai Performance diperoleh sebesar 0,231618030.

Nilai aktual pada Tabel 10 dan Tabel 11 diperoleh dari keluaran hasil perlatihan dan pengukuran kinerja. Nilai error diperoleh dari perhitungan Target (Y). Nilai aktual SSE diperoleh berdasarkan perhitungan error dikuadratkan $\left(\operatorname{error}^{\wedge} 2\right)$. Nilai total SSE diperoleh dari penjumlahan nilai SSE secara keseluruhan, sedangkan nilai Performance (Perf) diperoleh dari total SSE dibagi 8 , dengan 8 merupakan jumlah baris data. Berdasarkan hasil perlatihan dan pengukuran kinerja dengan penggunaan aplikasi MATLAB dan Ms. Excel, terdapat kesesuaian (valid).

\#3) Perlatihan dan pengukuran kinerja dengan metode metode bayesian regulation

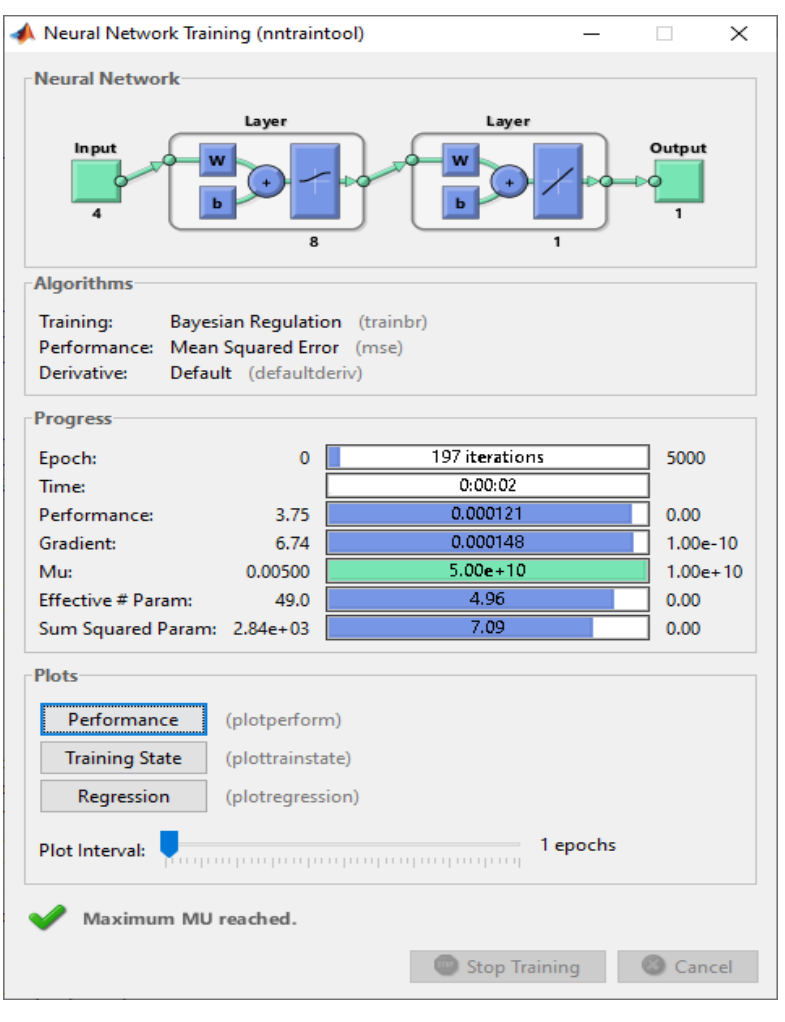

Gambar 7. Perlatihan Model 4-8-1 (trainbr)

Berdasarkan Gambar 7 dapat dijelaskan, bahwa hasil perlatihan dengan penggunaan fungsi trainoss pada model 4-8-1 dihasilkan epoch sebesar 197 iterasi dengan waktu latih selama 2 detik.

Hasil perlatihan terhadap model arsitekstur 4-8-1 (trainbr), seperti ditunjukkan pada Tabel 12.

Tabel 12. Hasil Perlatihan Model Arsitektur 4-8-1 (trainbr)

\begin{tabular}{ccccc}
\hline \multirow{2}{*}{ Target (Y1) } & \multicolumn{4}{c}{ Epoch 197} \\
\cline { 2 - 4 } & Actual & Error & SSE & Performance \\
\hline 0,7423 & 0,7265 & 0,0158 & 0,00024868 & \\
0,1511 & 0,1471 & 0,0040 & 0,00001571 & \\
0,6878 & 0,6940 & $-0,0062$ & 0,00003842 & \\
0,6640 & 0,6732 & $-0,0092$ & 0,00008516 & 0,00012119 \\
0,1023 & 0,1099 & $-0,0076$ & 0,00005822 & \\
0,1227 & 0,1080 & 0,0147 & 0,00021594 & \\
0,1023 & 0,1190 & $-0,0167$ & 0,00027991 & \\
0,1045 & 0,0993 & 0,0052 & 0,00002745 & \\
\cline { 2 - 4 } & & Total SSE & 0,00096950 & \\
\cline { 3 - 4 } & & MSE & 0,00012119 & \\
\cline { 3 - 4 }
\end{tabular}

Berdasarkan Tabel 12 dapat dijelaskan, bahwa hasil perlatihan dengan model arsitektur 4-8-1 dengan nilai konvergensi pada iterasi ke 197 dengan nilai Performance sebesar 0,00012119.

Hasil pengukuran kinerja terhadap model arsitektur 48-1 (trainoss), seperti ditunjukkan pada Tabel 13.

DOI: https://doi.org/10.29207/resti.v5i2.3031

Lisensi: Creative Commons Attribution 4.0 International (CC BY 4.0) 
Tabel 13. Hasil pengukuran kinerja terhadap arsitektur jaringan syaraf 4-8-1 (trainbr)

\begin{tabular}{ccccc}
\hline \multirow{2}{*}{ Target (Y2) } & \multicolumn{4}{c}{ Epoch 1 } \\
\cline { 2 - 4 } & Actual & Error & SSE & Performance \\
\hline 0,6063 & 0,7938 & $-0,1875$ & 0,035156331 & \\
0,2854 & 0,4591 & $-0,1737$ & 0,030181099 & \\
0,7222 & 0,5005 & 0,2217 & 0,049132205 & \\
0,4308 & 0,4752 & $-0,0444$ & 0,001973598 & 0,014848077 \\
0,1133 & 0,1596 & $-0,0463$ & 0,002141498 & \\
0,1058 & 0,1128 & $-0,0070$ & 0,000049099 & \\
0,1174 & 0,1051 & 0,0123 & 0,000150767 & \\
0,1006 & 0,1007 & $-0,0001$ & 0,000000015 & \\
& & Total SSE & 0,118784613 & \\
\cline { 3 - 4 } & & MSE & 0,014848077 &
\end{tabular}

Berdasarkan Tabel 9 dapat dijelaskan, bahwa nilai Performance diperoleh sebesar 0,014848077.

Nilai aktual pada Tabel 12 dan Tabel 13 diperoleh dari keluaran hasil perlatihan dan pengukuran kinerja. Nilai error diperoleh dari perhitungan Target (Y). Nilai aktual SSE diperoleh berdasarkan perhitungan error dikuadratkan $\left(\operatorname{error}^{\wedge} 2\right)$. Nilai total SSE diperoleh dari penjumlahan nilai $S S E$ secara keseluruhan, sedangkan nilai Performance (Perf) diperoleh dari total SSE dibagi 8 , dengan 8 merupakan jumlah baris data. Berdasarkan hasil perlatihan dan pengukuran kinerja dengan penggunaan aplikasi MATLAB dan Ms. Excel, terdapat kesesuaian (valid).

@ 3.b) Jaringan syaraf model arsitektur 4-10-1

Tampilan hasil perlatihan terhadap model arsitektur 410-1 (trainbr), seperti ditunjukkan pada Gambar 8

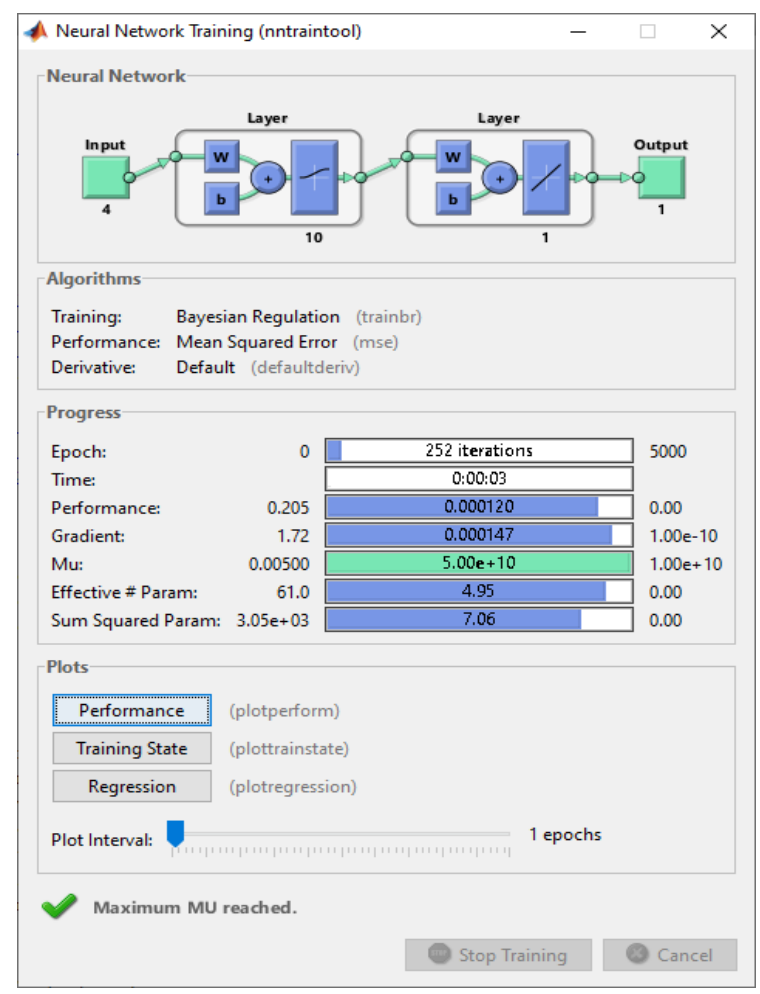

Gambar 8. Perlatihan Model 4-10-1 (trainbr)
Berdasarkan Gambar 6 dapat dijelaskan, bahwa hasil perlatihan dengan penggunaan fungsi trainoss pada model 4-10-1 dihasilkan epoch sebesar 2527 iterasi dengan waktu latih selama 3 detik.

Gambar 8 menjelaskan bahwa hasil perlatihan penggunaan fungsi trainbr pada model 4-10-1 menghasilkan epoch sebesar 2527 iterasi dengan waktu latih selama 3 detik.

Hasil perlatihan terhadap model arsitekstur 4-10-1 (trainbr), seperti ditunjukkan pada Tabel 14.

Tabel 14. Hasil Perlatihan Model Arsitektur 4-10-1 (trainbr)

\begin{tabular}{ccccc}
\hline \multirow{2}{*}{ Target (Y1) } & \multicolumn{4}{c}{ Epoch 252 } \\
\cline { 2 - 4 } & Actual & Error & SSE & Performance \\
\hline 0,7423 & 0,7266 & 0,0157 & 0,00024553 & \\
0,1511 & 0,1471 & 0,0040 & 0,00001571 & \\
0,6878 & 0,6940 & $-0,0062$ & 0,00003842 & \\
0,6640 & 0,6731 & $-0,0091$ & 0,00008333 & 0,00012038 \\
0,1023 & 0,1098 & $-0,0075$ & 0,00005671 & \\
0,1227 & 0,1080 & 0,0147 & 0,00021594 & \\
0,1023 & 0,1190 & $-0,0167$ & 0,00027991 & \\
0,1045 & 0,0993 & 0,0052 & 0,00002745 & \\
\cline { 2 - 4 } & & Total SSE & 0,00096300 & \\
\cline { 3 - 4 } & & MSE & 0,00012038 &
\end{tabular}

Berdasarkan Tabel 14 dapat dijelaskan, bahwa hasil perlatihan dengan model arsitektur 4-10-1 dengan nilai konvergensi pada iterasi ke 252 dengan nilai Performance sebesar 0,00012038.

Hasil pengukuran kinerja terhadap model arsitektur 410-1 (trainbr), seperti ditunjukkan pada Tabel 15.

Tabel 15. Hasil Pengujian Model Arsitektur 4-10-1 (trainbr)

\begin{tabular}{ccccc}
\hline \multirow{2}{*}{ Target (Y2) } & \multicolumn{4}{c}{ Epoch 1 } \\
\cline { 2 - 4 } & Actual & Error & SSE & Performance \\
\hline 0,6063 & 0,7944 & $-0,1881$ & 0,035381692 & \\
0,2854 & 0,4587 & $-0,1733$ & 0,030042277 & \\
0,7222 & 0,5001 & 0,2221 & 0,049309692 & \\
0,4308 & 0,4748 & $-0,0440$ & 0,001938218 & 0,014875502 \\
0,1133 & 0,1595 & $-0,0462$ & 0,002132253 & \\
0,1058 & 0,1128 & $-0,0070$ & 0,000049099 & \\
0,1174 & 0,1051 & 0,0123 & 0,000150767 & \\
0,1006 & 0,1007 & $-0,0001$ & 0,000000015 & \\
& & Total SSE & 0,119004012 & \\
\cline { 3 - 4 } & & MSE & 0,014875502 &
\end{tabular}

Berdasarkan Tabel 15 dapat dijelaskan, bahwa nilai Performance diperoleh sebesar 0,014875502.

Nilai aktual pada Tabel 14 dan Tabel 15 diperoleh dari keluaran hasil perlatihan dan pengukuran kinerja. Nilai error diperoleh dari perhitungan Target (Y). Nilai aktual SSE diperoleh berdasarkan perhitungan error dikuadratkan (error ${ }^{\wedge}$ ). Nilai total $S S E$ diperoleh dari penjumlahan nilai $S S E$ secara keseluruhan, sedangkan nilai Performance (Perf) diperoleh dari total SSE dibagi 8 , dengan 8 merupakan jumlah baris data. Berdasarkan hasil perlatihan dan pengukuran kinerja dengan penggunaan aplikasi MATLAB dan Ms. Excel, terdapat kesesuaian (valid).

DOI: https://doi.org/10.29207/resti.v5i2.3031

Lisensi: Creative Commons Attribution 4.0 International (CC BY 4.0) 


\subsection{Analisis Hasil dan Evaluasi}

Berdasarkan hasil perlatihan dan pengujian penggunaan aplikasi Matlab 2011b dan Ms. Excel, tahapan selanjutnya adalah menganalisis hasil dan mengevaluasi untuk memperoleh model arsitektur dan fungsi perlatihan terbaik.

Tabel 16. Hasil Analisis fungsi perlatihan yang digunakan

\begin{tabular}{ccccc}
\hline \multirow{2}{*}{ Model } & \multirow{2}{*}{ Metode } & $\begin{array}{c}\text { Fungsi } \\
\text { Training }\end{array}$ & $\begin{array}{c}\text { Epoch } \\
\text { (Iterasi) }\end{array}$ & $\begin{array}{c}\text { MSE Testing / } \\
\text { Performance }\end{array}$ \\
\hline \multirow{4}{*}{ Backpropagation Standard } & traingd & 1445 & 0,0633344819 \\
4-1 One-Step Secant (OSS) & trainoss & 52 & 0,0608435222 \\
Bayesian regulation & trainbr & 197 & 0,0148480766 \\
Backpropagation Standard & traingd & 2420 & 0,0113951975 \\
4-10-1 One-Step Secant (OSS) & trainoss & 577 & 0,2316180300 \\
Bayesian regulation & trainbr & 252 & 0,0148755015 \\
\hline
\end{tabular}

Berdasarkan Tabel 16 dapat dijelaskan, bahwa perbandingan terhadap masing-masing metode fungsi perlatihan dan pengukuran kinerja yang telah dilakukan. Berdasarkan analisis, terdapat 2 nilai MSE Testing (Performance) dengan nilai terendah, yaitu (i) model arsitektur 4-10-1 berbasis metode backpropagation standar dengan epoch 2420 iterasi dan nilai MSE 0,0113951975 dan (ii) model arsitektur 4-81 dengan metode Bayesian regulation dengan epoch sebesar 197 iterasi dan nilai MSE Testing/Performance sebesar 0,0148480766.

Metode Bayesian regulation terpilih menjadi fungsi perlatihan terbaik, walaupun dengan nilai MSE nomor dua terendah dibandingkan backpropagation standar, karena mampu dengan fungsi perlatihan terhadap jaringan syaraf lebih optimal. Tampilan nilai $M S E$ Testing/Performance, seperti ditunjukkan pada Gambar 9.

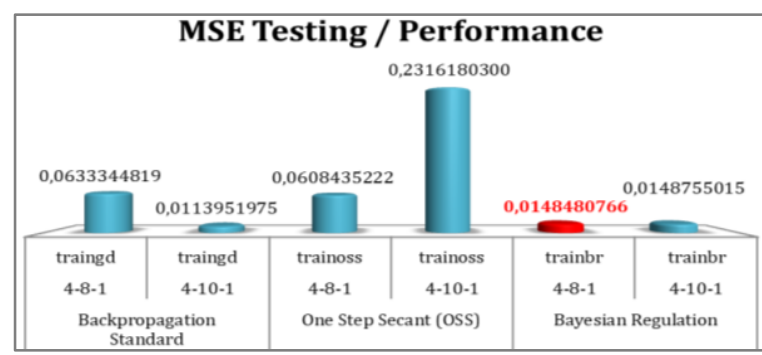

Gambar 9. Tampilan nilai MSE Testing/Performance

Berdasarkan Gambar 9 ditunjukkan nilai $M S E$ Testing/Performance dari masing-masing model arsitektur dan fungsi perlatihan yang digunakan. Tampilan nilai Epoch, seperti ditunjukkan pada Gambar 10.

Berdasarkan Gambar 10 ditunjukkan nilai Epoch dari masing-masing model arsitektur dan fungsi perlatihan yang digunakan dengan fungsi perlatihan dengan metode bayesian regulation dan model arsitektur jaringan 4-8-1 sebagai pilihan terbaik.

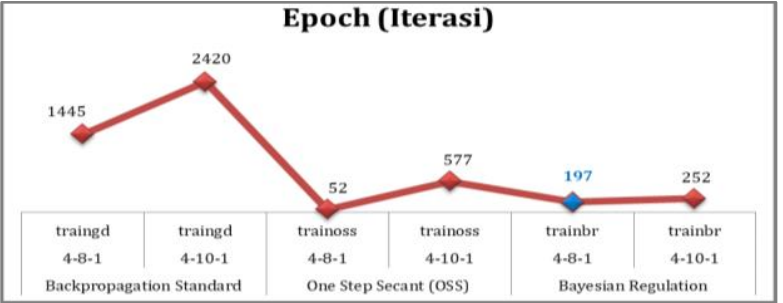

Gambar 10. Tampilan nilai Epoch

\section{Kesimpulan}

Berdasarkan hasil dan pembahasan, maka disimpulkan sesuai tujuan dan sasaran penelitian. Fungsi perlatihan dengan metode Bayesian regulation dapat digunakan dan dimanfaatkan untuk melakukan peramalan/prediksi bencana alam di Indonesia, karena waktu perlatihan untuk pencapaian konvergensi tidak terlalu lama dan Performance yang dihasilkan cukup baik dibandingkan dengan penggunaan metode backpropagation standar maupun metode One-Step Secant (OSS). Hal itu berdasarkan analisis, bahwa fungsi perlatihan bayesian regulation (trainbr) mampu untuk perlatihan jaringan syaraf dengan tingkat keoptimalan lebih baik, yaitu dihasilkan nilai epoch dan Performance perlatihan yang lebih cepat dan MSE pengukuran kinerja yang cukup baik walaupun fungsi perlatihan dengan metode backpropagation standar dengan nilai MSE pengukuran kinerja lebih kecil, tetapi backpropagation standar perlu waktu yang cukup lama untuk perlatihan jaringan syaraf, terbukti dengan penunjukan nilai epoch lebih besar dibandingkan dengan kedua metode lain.

\section{Daftar Rujukan}

[1] H. K. Ghritlahre and R. K. Prasad, "Prediction of Thermal Performance of Unidirectional Flow Porous Bed Solar Air Heater with Optimal Training Function Using Artificial Neural Network," Energy Procedia, vol. 109, pp. 369-376, 2017.

[2] E. Siregar, H. Mawengkang, E. B. Nababan, and A. Wanto, "Analysis of Backpropagation Method with Sigmoid Bipolar and Linear Function in Prediction of Population Growth," Journal of Physics: Conference Series, vol. 1255, no. 1, p. 012023, 2019.

[3] M. Tyrtaiou, A. Papaleonidas, A. Elenas, and L. Iliadis, "Accomplished Reliability Level for Seismic Structural Damage Prediction Using Artificial Neural Networks," in Proceedings of the 21st EANN (Engineering Applications of Neural Networks) 2020 Conference. EANN 2020. Proceedings of the International Neural Networks Society, 2020, vol. 2, pp. 85-98.

[4] B. Febriadi, Z. Zamzami, Y. Yunefri, and A. Wanto, "Bipolar function in backpropagation algorithm in predicting Indonesia's coal exports by major destination countries," IOP Conference Series: Materials Science and Engineering, vol. 420, no. 1, p. 012087, 2018.

[5] N. Nasution, A. Zamsuri, L. Lisnawita, and A. Wanto, "PolakRibiere updates analysis with binary and linear function in determining coffee exports in Indonesia," IOP Conference Series: Materials Science and Engineering, vol. 420, no. 1, pp. $1-9,2018$.

[6] A. Dolara, F. Grimaccia, S. Leva, M. Mussetta, and E. Ogliari, "Comparison of training approaches for photovoltaic forecasts by means of machine learning," Applied Sciences (Switzerland), vol. 8 , no. 2,2018 . 
[7] H. Wang, R. Czerminski, and A. C. Jamieson, "Neural Networks and Deep Learning," in The Machine Age of Customer Insight, P. Einhorn, M., Löffler, M., de Bellis, E., Herrmann, A. and Burghartz, Ed. Emerald Publishing Limited, 2021, pp. 91-101.

[8] I. Cong, S. Choi, and M. D. Lukin, "Quantum convolutional neural networks," Nature Physics, vol. 15, no. 12, pp. 12731278, 2019.

[9] B. S. Rem et al., "Identifying quantum phase transitions using artificial neural networks on experimental data," Nature Physics, vol. 15, no. 9, pp. 917-920, 2019

[10]R. Novickis, D. J. Justs, K. Ozols, and M. Greitans, "An Approach of Feed-Forward Neural Network," Electronics, vol. 9, no. 12 , p. 2193, 2020.

[11]F. Cichos, K. Gustavsson, B. Mehlig, and G. Volpe, "Machine learning for active matter," Nature Machine Intelligence, vol. 2, no. 2, pp. 94-103, 2020.

[12]C. T. Chen and G. X. Gu, "Generative Deep Neural Networks for Inverse Materials Design Using Backpropagation and Active Learning," Advanced Science, vol. 7, no. 5, pp. 1-10, 2020.

[13]R. García-Ródenas, L. J. Linares, and J. A. López-Gómez, "Memetic algorithms for training feedforward neural networks: an approach based on gravitational search algorithm," Neural Computing and Applications, vol. 33, pp. 2561-2588, 2020.

[14]E. Yan, J. Song, C. Liu, J. Luan, and W. Hong, "Comparison of support vector machine, back propagation neural network and extreme learning machine for syndrome element differentiation," Artificial Intelligence Review, vol. 53, no. 4, pp. 2453-2481, 2020.

[15]L. Yang and A. Shami, "On hyperparameter optimization of machine learning algorithms: Theory and practice," Neurocomputing, vol. 415, pp. 295-316, 2020.

[16]I. D. Uwanuakwa and P. Akpinar, "Investigations on the Influence of Variations in Hidden Neurons and Training Data Percentage on the Efficiency of Concrete Carbonation Depth Prediction with ANN," Advances in Intelligent Systems and Computing, vol. 1095, pp. 958-965, 2020.

[17]S. Alsammarraie and N. K. Hussein, "A New Hybrid Grasshopper Optimization - Backpropagation for Feedforward Neural Network Training," Tikrit Journal of Pure Science, vol. 25 , no. 1, pp. 118-127, 2020

[18]E. Bas, E. Egrioglu, and U. Yolcu, "A hybrid algorithm based on artificial bat and backpropagation algorithms for multiplicative neuron model artificial neural networks," Journal of Ambient Intelligence and Humanized Computing, pp. 1-9, 2020.

[19]I. T. Sui Kim, V. Sethu, S. K. Arumugasamy, and A. Selvarajoo, "Fenugreek seeds and okra for the treatment of palm oil mill effluent (POME) - Characterization studies and modeling with backpropagation feedforward neural network (BFNN)," Journal of Water Process Engineering, vol. 37, no. 101500, pp. 1-16, 2020 .

[20]I. C. Afolabi, S. I. Popoola, and O. S. Bello, "Modeling pseudosecond-order kinetics of orange peel-paracetamol adsorption process using artificial neural network," Chemometrics and Intelligent Laboratory Systems, vol. 203, no. 104053, pp. 1-47, 2020.

[21] Isha, A. S. Chaudhary, and D. K. Chaturvedi, "Effects of Activation Function and Input Function of ANN for Solar Power Forecasting," in Lecture Notes in Networks and Systems, vol. 94, M. L. Kolhe, S. Tiwari, M. C. Trivedi, and K. K. Mishra, Eds. Springer, 2020, pp. 329-342.

[22]A. Panyafong, N. Neamsorn, and C. Chaichana, "Heat load estimation using Artificial Neural Network," Energy Reports, vol. 6, pp. 742-747, 2020.

[23]K. Kumar, V. Singh, and T. Roshni, "Efficacy of hybrid neural networks in statistical downscaling of precipitation of the Bagmati river basin," Journal of Water and Climate Change, vol. 11, no. 4, pp. 1302-1322, 2020.

[24]M. Žic, V. Subotić, S. Pereverzyev, and I. Fajfar, "Solving CNLS problems using Levenberg-Marquardt algorithm: A new fitting strategy combining limits and a symbolic Jacobian matrix," Journal of Electroanalytical Chemistry, vol. 866, no. 114171, pp. 1-9, 2020.

25]J. Bilski, B. Kowalczyk, A. Marchlewska, and J. M. Zurada, "Local Levenberg-Marquardt Algorithm for Learning Feedforwad Neural Networks," Journal of Artificial Intelligence and Soft Computing Research, vol. 10, no. 4, pp. 299-316, 2020.

26]N. L. W. S. R. Ginantra, M. A. Hanafiah, A. Wanto, R. Winanjaya, and H. Okprana, "Utilization of the Batch Training Method for Predicting Natural Disasters and Their Impacts," IOP Conf. Series: Materials Science and Engineering, vol. 1071, no. 012022, pp. 1-7, 2021

27]R. Jayaseelan, G. Pandulu, and G. Ashwini, "Neural Networks for the Prediction of Fresh Properties and Compressive Strength of Flowable Concrete," Journal of Urban and Environmental Engineering, vol. 13, no. 1, pp. 183-197, 2019.

28]H. Espitia, I. Machon, and H. Lopez, "Control of a Microturbine Using Neural Networks," in Communications in Computer and Information Science, vol. 1052, J. C. Figueroa-García, M. Duarte-González, S. Jaramillo-Isaza, A. D. Orjuela-Cañon, and Y. D.-G. (Eds.), Eds. Springer, 2019, pp. 202-213.

[29]D. Gong, J. Feng, W. Xiao, and S. Sun, "Spectral Reconstruction Based on Bayesian regulation Neural Network," in Smart Innovation, Systems and Technologies, vol. 179, R. Kountchev, S. Patnaik, J. Shi, and M. N. Favorskaya, Eds. Springer, 2019, pp. $77-85$.

[30]U. G. Inyang, E. E. Akpan, and O. C. Akinyokun, "A Hybrid Machine Learning Approach for Flood Risk Assessment and Classification," International Journal of Computational Intelligence and Applications, vol. 19, no. 2, pp. 1-20, 2020.

31]T. Afriliansyah and Z. Zulfahmi, "Prediction of Life Expectancy in Aceh Province by District City Using the Cyclical Order Algorithm," International Journal of Information System \& Technology, vol. 3, no. 2, pp. 268-275, 2020

[32] G. S. Rao, S. S. Rani, and B. P. Rao, "Computed Tomography Medical Image Compression using Conjugate Gradient," 2019 International Conference on Wireless Communications, Signal Processing and Networking (WiSPNET), pp. 169-173, 2019.

[33]Q. H. Nguyen et al., "A Novel Hybrid Model Based on a Feedforward Neural Network and One Step Secant Algorithm for Prediction of Load-Bearing Capacity of Rectangular Concrete-Filled Steel Tube Columns," Molecules, vol. 25, no. 15 , pp. 1-26, 2020.

[34]M. Zandieh, A. Azadeh, B. Hadadi, and M. Saberi, "Application of Artificial Neural Networks for Airline Number of Passenger Estimation in Time Series State," Journal of Applied Sciences, vol. 9, no. 6, pp. 1001-1013, 2009.

35]A. Perera, H. Azamathulla, and U. Rathnayake, "Comparison of different artificial neural network ( ANN ) training algorithms to predict the atmospheric temperature in Tabuk, Saudi Arabia," Journal MAUSAM, vol. 71, no. 2, pp. 233-244, 2020

36]C. Perez, Big Data and Deep Learning Examples with Matlab. Lulu Press, Inc, 2020.

[37]P. Parulian et al., "Analysis of Sequential Order Incremental Methods in Predicting the Number of Victims Affected by Disasters," Journal of Physics: Conference Series, vol. 1255, no. 1, p. 012033, 2019.

38]C. K. Arthur, V. A. Temeng, and Y. Y. Ziggah, "Performance Evaluation of Training Algorithms in Backpropagation Neural Network Approach to Blast-Induced Ground Vibration Prediction," Ghana Mining Journal, vol. 20, no. 1, pp. 20-33, 2020.

[39]BNPB, "Infografis Bencana," Geoportal Kebencanaan Indonesia, 2021. [Online]. Available: https://gis.bnpb.go.id/. [Accessed: 17-Mar-2021].

[40]S. Setti and A. Wanto, "Analysis of Backpropagation Algorithm in Predicting the Most Number of Internet Users in the World," JOIN (Jurnal Online Informatika), vol. 3, no. 2, pp. 110-115, 2018. 